\title{
IS IT REALLY FOR THE EUROPEAN COMMUNITY TO IMPLEMENT ANTI-TERRORISM UN SECURITY COUNCIL RESOLUTIONS?
}

Bотн before and after the terrorist attacks of 11 September 2001, the UN Security Council adopted several resolutions aimed at the Taliban, Osama Bin Laden and the Al-Qaeda network, and at individuals and entities associated with them. More specifically, it called on all the Members of the UN to freeze the funds which they controlled. A UN Sanctions Committee was entrusted with the task of identifying the persons concerned and the financial resources to be frozen, and of considering requests for exemption. The EC implemented those resolutions by adopting, among others, Regulation 881/2002, which contains a list of the persons concerned and is regularly reviewed by the Commission on the basis of the Sanctions Committee's updates.

Two applicants, whose assets had been frozen, sought the annulment of the Regulation under Article 230 EC. In Cases T-306/ 01 (Yusuf) and T-315/01 (Kadi), the Court of First Instance ("CFI") rejected their claims. Two main questions arose in these separate but very similar cases: first, whether the Council had the necessary competence to adopt the Regulation and, second, whether the Regulation violated the applicants' fundamental rights.

The Regulation is based on Articles 60, 301 and 308 EC. Articles 60 and 301 read together empower the Community to adopt financial sanctions in cases where urgent measures adopted within the framework of the Common Foreign and Security Policy ("CFSP") are required to "interrupt or reduce, in part or completely, economic relations with one or more third countries". The CFI accepted the applicants' argument that Articles 60 and 301 could not constitute, on their own, an adequate legal basis, insofar as the Regulation provided for the adoption of measures directed at individuals rather than third countries and as there was 
no sufficient link in this case between the sanctions laid down in the Regulation and a country.

The CFI also held that Article 308 could not serve as an adequate legal basis on its own, as the Regulation sought to attain CFSP objectives under the second pillar of the EU Treaty and not an objective of the EC Treaty, be it an objective expressly mentioned in Articles 2 and 3 or the more general objective of international peace and security. In particular, the CFI dismissed the argument that the measures laid down in the Regulation could be authorised by the object of establishing a common commercial policy, since the Community's commercial relations with third countries were not at stake in this case. It further noted that the implementation of the Security Council resolution by the Member States rather than by the Community was not capable of giving rise to a plausible and serious danger of discrepancies in the application of the freezing of funds from one Member State to another, and that a mere finding of a risk of disparities between the various national rules, and a theoretical risk of obstacles to the free movement of capital or payments or of distortions of competition liable to result therefrom, could not justify the choice of Article 308 as the Regulation's legal basis. In broader terms, the CFI held that this article could not be interpreted as giving the institutions general authority to rely on it as a basis with a view to attaining one of the objectives of the EU, as opposed to the EC, Treaty (for a comprehensive study on Article 308 EC, see R. Schütze, "Organised Change towards an 'Ever Closer Union': Article 308 EC and the Limits to the Community's Legislative Competence", (2003) 22 Y.E.L. 79).

However, the CFI went on to find that the combined reliance on Articles 60, 301 and 308 EC granted competence to the Community to adopt the Regulation. It reasoned that Articles 60 and 301, by empowering the Council to impose economic and financial sanctions on third countries in specific circumstances, established a bridge between the first and the second pillars of the EU Treaty. Article 308 therefore justified the extension, under similar conditions, of the imposition of economic and financial sanctions on individuals, in connection with the fight against international terrorism: "Recourse to Article 308 EC, in order to supplement the powers to impose economic and financial sanctions conferred on the Community by Articles 60 and 301 EC, is justified by the consideration that, as the world now stands, states can no longer be regarded as the only source of threats to international peace and security". 
This reasoning is disappointing, if not contradictory. On the one hand, the CFI expressly stated that Article 308 EC could not be used as a basis for a Community legislative measure which aims to attain one of the objectives of the EU Treaty. On the other hand, it accepted that the scope of Articles 60 and 301 could be extended to situations which fell outside their ambit, precisely on the basis of Article 308. However, and as the CFI itself noticed, the current three-pillar structure of the EU makes the Union and the Community integrated, but nonetheless separate, legal orders, as confirmed by Article 47 EU. Thus, the EU should not use Community powers to impose sanctions for breaches of second pillar provisions, beyond what is provided in the EC Treaty. The sole fact that the Council adopted the Regulation unanimously should not warrant such an extension of Community competence.

After establishing that the Council was empowered to adopt the Regulation, the CFI discussed whether it infringed the applicants' fundamental rights, thus providing the opportunity to consider the legal effects in the Community legal order of the UN Charter and Security Council resolutions.

The CFI ruled that it was not empowered to examine the legality of UN Security Council resolutions, even in relation to human rights. It noted that, from the standpoint of international law, the obligations of UN Members under the UN Charter clearly prevailed over every other obligation of domestic law or of international treaty law including obligations under the EC Treaty. Under Article 27 of the Vienna Convention on the Law of Treaties, a party may not invoke the provisions of its internal law as justification for its failure to perform a treaty. Moreover, Article 103 of the UN Charter provides that, "in the event of a conflict between the obligations of the Members of the United Nations under the present Charter and their obligations under any other international agreement, their obligations under the present Charter shall prevail". Furthermore, that primacy extends to decisions contained in a resolution of the Security Council, in accordance with Article 25 of the Charter, under which UN Members agree to accept and carry out the decisions of the Security Council. With regard more specifically to the relations between the obligations of the Member States of the Community by virtue of the UN Charter and their obligations under Community law, the CFI held that the Community was also bound by Security Council resolutions on the basis of Articles 307 and 224 EC, as interpreted in International Fruit Company (Joined Cases $21 / 72$ to 24/72 [1972] E.C.R. 1219).

It is true, from the point of view of international law, that Member States and the Community must comply with their 
international obligations: pacta sunt servanda. The Vienna Convention does not address the question, from the point of view of "internal" Community law, of the effects of international law (for a more extensive analysis, see P. Eeckhout, "Does Europe's Constitution Stop at the Water's Edge?", Walter Van Gerven Lectures (5), at 23). However, by stating that it could not review the legality of UN law, the CFI took a clear stance that international treaties automatically prevailed within the Community, thus defining the Community legal order as a monist system. Further, since EC law has supremacy over national law, Member States are constrained to adopt a monist approach to their international obligations once implemented through a Community instrument, notwithstanding their own constitutional traditions. That, in turn, deprives national courts of the power which they may otherwise have had under their domestic law to assess the compatibility of international law with fundamental rights.

Probably aware that its approach could deprive individuals of any right to judicial review, be it at Community or at national level, the CFI went on to declare itself competent "to check, indirectly, the lawfulness of the resolutions of the Security Council in question, with regard to ius cogens, understood as a body of higher rules of public international law binding on all subjects of international law, including the bodies of the United Nations, and from which no derogation is possible". In light of the nature of ius cogens as a supreme source of law, the CFI assessed whether the Regulation which implemented UN resolutions infringed the applicants' right to property, their right to be heard and their right to an effective judicial remedy, and concluded that they did not.

It is understandable that the CFI felt bound to mitigate the radical conclusion which it reached on the effects of UN law in "internal" Community law by relying on the supreme character of ius cogens (the content of which is, incidentally, subject to heated debates), so as to guarantee the protection of the applicants' fundamental rights. One nonetheless wonders how the CFI ever managed to reach this stage: the Regulation should have been annulled for lack of competence, and in any event, nothing in either international law or Community law prevented the CFI from assessing its compatibility with fundamental rights on the basis of the general principles of Community law.

Both cases are now under appeal. It is hoped that the European Court of Justice will adopt a more orthodox reasoning than the CFI in its judgments in cases C-402/05 (Kadi) and C-415/05 (Yusuf). 